\title{
Using Steel-Smelting Slag as a Raw Material Component in the Production of Asphalt Concrete
}

\author{
Dmitry Kuznetsov ${ }^{1 *}$, Marina Vysotskaya ${ }^{1}$, and Albert Burgonutdinov ${ }^{2}$ \\ ${ }^{1}$ Belgorod State Technological University VG Shukhov, Kostukova str., 46, 308012, Belgorod, \\ Russia \\ ${ }^{2}$ Perm National Research Polytechnic University, Komsomolsky Prospect, 29, 614990, Perm, Russia
}

\begin{abstract}
The possibility of using polydisperse steel-smelting slag for the production of type B asphalt concrete is investigated, the possibility of its use as a mineral powder, crushing screening and crushed stone is considered. As a result of the study, it was found that a promising area for the use of slag raw materials in the technology for the preparation of asphalt mixes is: as a mineral powder - without additional processing steps; crushing screening with the development of additional technological operations. The use of raw materials as crushed stone is impractical because of the high average density of the final asphalt mixture. Based on the test results, the characteristics of the fatigue properties of asphalt concrete from fine-grained dense mixtures of type B made on mineral powders from slag and limestone were obtained. It was established that at the initial moment, a large number of cycles to failure are characterized by compositions on slag powder, however, samples from this series tested after 45 days showed a significant rigidity increase and were destroyed earlier than similar samples on limestone. Obviously, this phenomenon is associated with an increase in the brittle properties of the material due to the formation of crystallization-condensation bonds in the structure of asphalt concrete containing slag.
\end{abstract}

\section{Introduction}

Steel-smelting slag is a product obtained due to the melting of fluxing rocks, which include limestone or lime. These rocks greatly simplify the smelting of metals, with their help harmful impurities that are contained in the ore are extracted.

The properties of steel-smelting slag largely depend on the chemical composition, as well as on the conditions of its cooling. Steel-smelting slags may include calcium silicates. Due to the variety of constituent substances, such slags have unique impurities in their

\footnotetext{
* Corresponding author: xidox@yandex.ru
} 
composition, which makes them a demanded raw material used for the production of building materials.

The composition and properties of steel-smelting slags determine the possible directions for their processing and use. Basically, they are used for the production of crushed stone (about half of the processed mass), about a third of their utilized amount is used as a circulating product (in the form of flux in a blast furnace and cupola furnaces), about a fifth part is processed into mineral fertilizers. A small amount is used for production of mineral wool products on a pilot scale, small quantities of these slags are granulated. When processing steel-smelting slag metal is extracted from them.

Steel-smelting slags are widely used in road construction when laying base layers and crushed stone coatings of highways [1-5]. For road construction purposes, slag is mainly suitable for the second discharge, a crystalline structure containing a small amount of lime burn grains. Such slag is used as the underlying base layers in the construction and reconstruction of roads. The compaction of such a base with watering leads over time to monolith it.

As experience [6-9] shows, steel-smelting slags can be effective when introduced into asphalt concrete. In particular, dispersed fractions of steelmaking slag can act as a mineral powder, provided they meet certain regulatory requirements (GOST R 52129-2003).

The raw material for the production of slag powder is slag waste from steel production with a piece size of $0-350 \mathrm{~mm}$. It is necessary to pay attention to the value of the total specific effective activity of natural radionuclides, the content of which should not exceed $740 \mathrm{~Bq} / \mathrm{kg}$.

The widespread use of steel-smelting slag is also associated with the solution of a number of environmental problems and the rational use of resources, due to the partial replacement of traditional mineral raw materials with slag. This helps to reduce the extraction and processing of natural stone materials. It should be noted that the cost of storing waste arising from the extraction and processing of iron ore has become close to the cost of mining the minerals themselves. The relevance of introducing slag waste into the production cycle is also due to environmental protection from pollution and its rehabilitation despite all the precautions the processes of extraction, transportation, processing of mineral resources and especially storage of the resulting by-products of processing are inevitably accompanied by the release of large amounts of polluting substances into the environment substances [10].

Current trends can be seen in road materials science, where, along with the basics of obtaining high-quality composites and structures, key positions are occupied by material savings, rational use of energy and mineral resources. In this regard, the need arises for the integrated implementation of all known and original areas in this area, among which the most popular is the integrated use of recycled materials.

Often, the use of technogenic raw materials in the production of building materials and structures makes it possible to reveal their useful and unique qualities, for example, such as the energy potential of the surface or structural features of the crystal lattice and chemical composition. Such an approach allows one to obtain products with sufficiently high physical, mechanical and operational characteristics, and sometimes with a unique set of properties.

It is known that technogenic raw materials are significantly different from traditional ones in chemical, mineralogical composition, moreover, these raw materials are often heterogeneous, therefore, in each case it is necessary to conduct studies to assess the possibility of using industrial waste. 


\section{Objects and methods}

Possibility of the integrated use of polydisperse steel-smelting slag for the production of asphalt concrete was considered in this paper.

The aim of the work was to find out which component the considered slag raw material could be used as in asphalt concrete mixes of type B for road coating.

The work used standard research methods for the components of the asphalt mix: crushed stone, sand, mineral powder and bitumen. The morphology of dispersed samples of slag and limestone mineral powders was studied using the scanning electron microscopy (SEM) method using a TESCAN MIRA 3 LMU high resolution scanning electron microscope. The intensity of the interaction of bitumen with mineral powders was estimated by studying the adhesion of mineral material and bitumen by selective dye adsorption [11], based on the ability of methylene blue dye to selectively adsorb from aqueous solutions on a mineral surface. The choice is due to the fact that the dye is practically not adsorbed on bitumen. The weight method for determining grip was also used.

The durability assessment of asphalt concrete samples was carried out by cyclic loading of samples on a Servo-pneumatic system CRT-NU (Cooper Research Technology). The loading frequency was $10 \mathrm{~Hz}$, the test temperature $+20^{\circ} \mathrm{C}$.

At the initial stage of the study, the characteristics of crushed stone, sand and mineral powder from the specified slag were studied for compliance with the requirements of regulatory documents governing their use in the composition of the road composite.

BND 60/90 bitumen was used in this research. Property indicators are presented in table. 1 .

Table 1. Properties of bitumen used.

\begin{tabular}{|l|c|c|}
\hline \multicolumn{1}{|c|}{ Indicator } & $\begin{array}{c}\text { Requirements } \\
\text { according to } \\
\text { GOST 22245-90 }\end{array}$ & $\begin{array}{c}\text { BND } \\
60 / 90\end{array}$ \\
\hline $\begin{array}{l}\text { Softening temperature according to ring-and-ball method, } \\
{ }^{\circ} \mathrm{C}\end{array}$ & not less than 47 & 48 \\
\hline Softening temperature change after heating, ${ }^{\circ} \mathrm{C}$ & not less than 5 & 4.9 \\
\hline Needle penetration depth at $25^{\circ} \mathrm{C}, 0.1 \mathrm{~mm}$ & $61-90$ & 75 \\
\hline $\begin{array}{l}\text { Penetration depth of the needle at } 25^{\circ} \mathrm{C} \text { after aging, } 0.1 \\
\text { mm }\end{array}$ & - & 52 \\
\hline Penetration depth of the needle at $0{ }^{\circ} \mathrm{C}, 0.1 \mathrm{~mm}$ & not less than 20 & 21 \\
\hline Tensile at $25^{\circ} \mathrm{C}, \mathrm{cm}$ & not less than 55 & $>130$ \\
\hline Tensile at $0{ }^{\circ} \mathrm{C}$ & not less than 3.5 & 3.8 \\
\hline Fragility temperature, ${ }^{\circ} \mathrm{C}$ & not higher than - & -22 \\
\hline The mass change after aging, $\%$ & - & 0 \\
\hline Dynamic viscosity at $135^{\circ} \mathrm{C}, \mathrm{Pa} * \mathrm{~s}$ & - & 259 \\
\hline Mark PG & - & $64-28$ \\
\hline
\end{tabular}

The bitumen used complies with regulatory requirements. 
Crushed stone plays an important role in the composition of asphalt concrete coatings of roads which receives and transfers the load from vehicles. For many regions the problem of high-quality crushed stone component for the preparation of asphalt mixes is very important. In this regard, the possibility of using the studied slag in the composition of the road composite would reduce the deficit of crushed stone in a number of regions.

In accordance with the table. 2, the physical and mechanical characteristics of crushed stone from steel-smelting slag also indicate its compliance with regulatory requirements and the possibility of using asphalt concrete.

Table 2. Physical and mechanical properties of crushed stone.

\begin{tabular}{|l|c|c|}
\hline \multicolumn{1}{|c|}{ Indicator } & GOST requirements & Actual value \\
\hline Bulk density, $\mathrm{kg} / \mathrm{m}^{3}$ & - & 1560 \\
\hline True density, $\mathrm{kg} / \mathrm{m}^{3}$ & - & 3.3 \\
\hline Average density, $\mathrm{kg} / \mathrm{m}^{3}$ & - & 2.96 \\
\hline Porosity, $\%$ & - & 10 \\
\hline Voidness, $\%$ & - & 41 \\
\hline Strength grade & - & $\mathrm{M} 1200$ \\
\hline Content of weak rocks, $\%$ & less than 5 & 2.1 \\
\hline Content of flaky grains, $\%$ & less than 15 & 5.8 \\
\hline Abrasion & - & И II \\
\hline Frost resistance & - & $>$ F 50 \\
\hline
\end{tabular}

The next stage of the study was the assessment of the conformity of slag properties with the requirements for fine aggregate - sand. The results of determining the particle size characteristics of sand from the crushing screening ща steel-smelting slag are presented in table 3 and show full compliance with the requirements of GOST. According to the data obtained, the particle size modulus of such sand was 3.6. This allows us to attribute it to coarse sand.

Table 3. Particle size distribution of sand from the crushing screening of slag.

\begin{tabular}{|l|c|c|c|c|c|c|c|}
\hline Size of sieves, $\mathrm{mm}$ & 2.5 & 1.25 & 0.63 & 0.315 & 0.14 & 0.071 & $<0.071$ \\
\hline Private rest, $\%$ & 33.0 & 29.0 & 18.0 & 9.0 & 7.0 & 1.5 & 2.5 \\
\hline Full rest, $\%$ & 33.0 & 62.0 & 80.0 & 89.0 & 96.0 & 97.5 & 100 \\
\hline Full passages, $\%$ & 67.0 & 38.0 & 20.0 & 11.0 & 4.0 & 2.5 & - \\
\hline
\end{tabular}

An important indicator in assessing the quality of sand is the content of clay particles, which should not exceed $-5 \%$ by weight. The test result showed that this value for the investigated slag sands is from 5.6 to $10 \%$, which does not correspond to GOST 3344-83.

In this regard, at the stage of evaluating the properties of the initial materials of the study, it was concluded that it is necessary to use additional mechanical dispersion to remove dusty and clay particles to use slag sand in the composition of asphalt concrete.

The most important component of the organomineral composite, which determines its physical and mechanical characteristics, is mineral powder, which together with bitumen forms a structured dispersed system that acts as a binder in asphalt concrete. This fact makes it possible to regulate the properties of road asphalt concrete by using fillers in its composition that can provide stable bonds at the "bitumen - mineral material" phase boundary.

The test results of the mineral powder of the investigated slag are presented in table 4 . 
Table 4. Characteristics of mineral powder made of steel-smelting slag.

\begin{tabular}{|c|c|c|}
\hline Indicators & $\begin{array}{l}\text { Values according to } \\
\text { GOST R 52129-2003 }\end{array}$ & Actual values \\
\hline $\begin{array}{l}\text { Grain composition, } \% \text { by weight: } \\
\text { smaller than } 1.25 \mathrm{~mm} \\
\text { smaller than } 0.315 \mathrm{~mm} \\
\text { smaller than } 0.071 \mathrm{~mm}\end{array}$ & $\begin{array}{l}\text { not less than } 95 \\
\text { from } 80 \text { to } 95 \\
\text { not less than } 60\end{array}$ & $\begin{array}{l}- \\
96.5 \\
84.9\end{array}$ \\
\hline Average density, $\mathrm{g} / \mathrm{cm}^{3}$ & - & 2.5 \\
\hline True density, $\mathrm{g} / \mathrm{cm}^{3}$ & - & 3.3 \\
\hline Porosity, $\%$, not less than & 40 & 22 \\
\hline $\begin{array}{l}\text { Swelling of samples from a mixture of } \\
\text { powder with bitumen, } \% \text {, less than }\end{array}$ & 3.0 & 2.21 \\
\hline Content of active $\mathrm{CaO}, \mathrm{MgO}, \%$ less than & 3.0 & 4.1 \\
\hline $\begin{array}{l}\text { Water resistance of samples from a } \\
\text { mixture of powder with bitumen, } \% \text {, not } \\
\text { less than }\end{array}$ & 0.7 & 0.75 \\
\hline $\begin{array}{l}\text { Long-term water resistance of samples } \\
\text { from a mixture of powder with } \\
\text { bitumen, } \% \text {, not less than }\end{array}$ & - & 0.69 \\
\hline $\begin{array}{l}\text { Bitumen consumption rate, } g \text {, not less } \\
\text { than }\end{array}$ & 80 & 60 \\
\hline
\end{tabular}

To evaluate and predict possible processes occurring at the "bitumen - mineral powder" phase micrographs of the surface of dispersed fillers shown in Fig. 1-2 were performed.

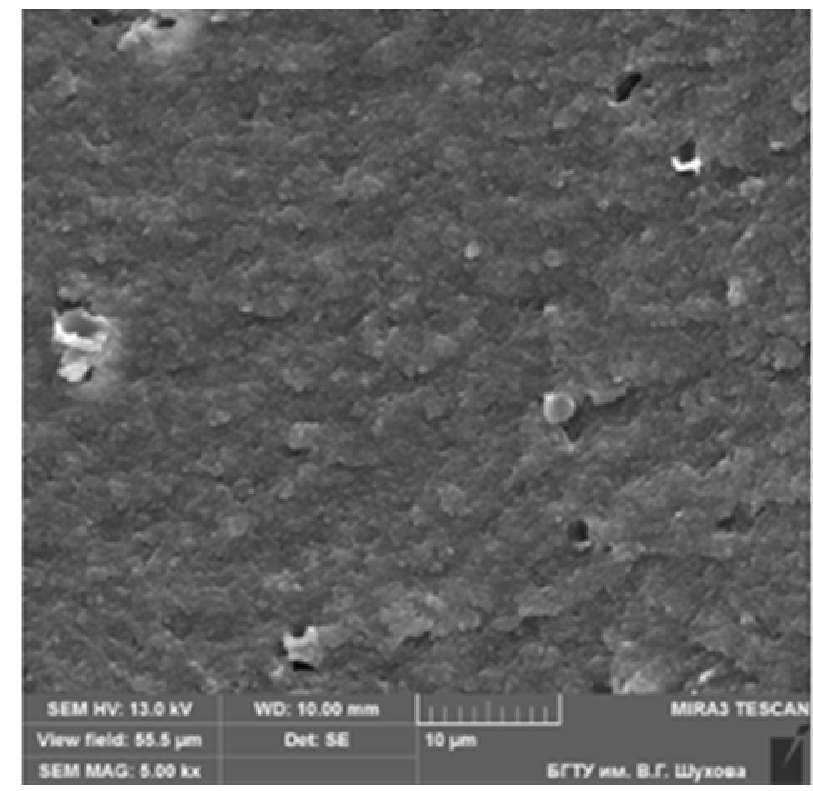

Fig. 1. Micrographs of mineral powders from limestone. 


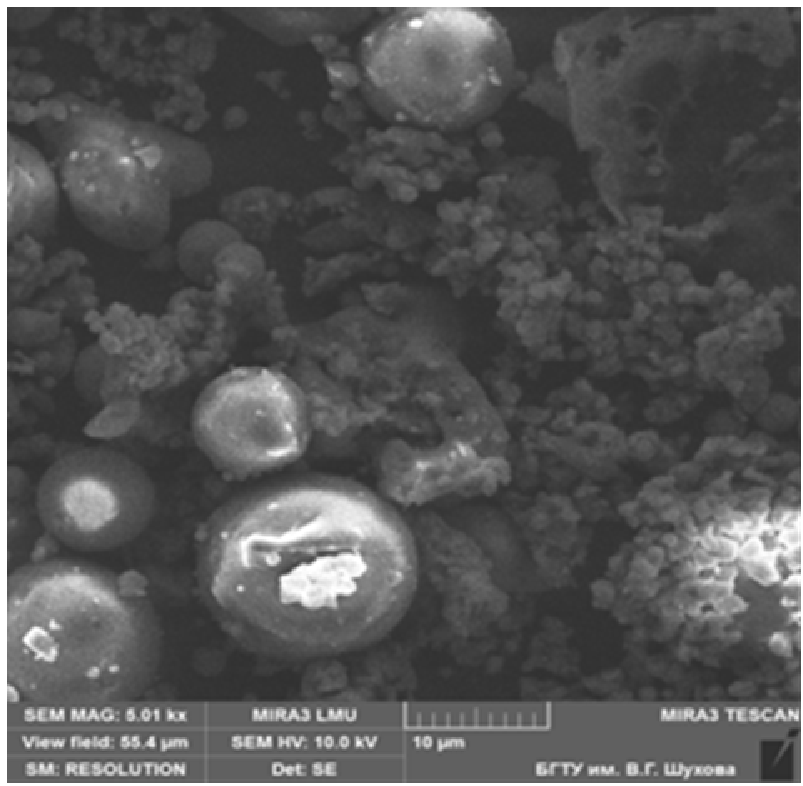

Fig.2. Micrographs of mineral powders from slag raw materials.

Table 5 shows that the dispersed slag component meets the requirements of GOST R 52129-2003. The water resistance of samples from a mixture of powder with bitumensphalt binder is $7 \%$ higher than the regulatory requirements, moreover, the long-term water resistance of the asphalt binder determined after 15 days in water showed quite high indicators, while there is a low rate of swelling and bitumen intensity. It should be noted that in the considered mineral powder from slag there is a overestimated content of $\mathrm{CaO}$. However, according to a number of studies [12-14] the $\mathrm{CaO}$ content to a certain concentration in the composition of the mineral powder contributes to the formation of strong adhesive contacts at the phase boundary and contributes to an increase in water resistance and corrosion resistance of the road composite. Obviously, the $\mathrm{CaO}$ content in the slag mineral powder in excess of the normalized value contributes to the water resistance indicators recorded during testing.

Microphotographs of the surface, Fig. 1-2 have shown spherical inclusions of metal characteristic of slag powders, which are powdered obviously with $\mathrm{CaO}$ particles.

Thus, the results of testing the asphalt binder give reason to believe that when using mineral powder from the investigated slag asphalt concrete of a sufficiently high quality can be obtained.

The validity of the preliminary conclusions made was confirmed by the test results of samples of type B asphalt concrete.

\section{Main part}

\subsection{The impact of slag mineral powder on the asphalt binder}

The study of the interaction of slag mineral powder with bitumen, with the aim of predicting the properties of asphalt concrete prepared using it was carried out on an asphalt binder - the binary system "bitumen-powder".

When preparing the asphalt binder the content of bitumen with respect to the mass of the powder was taken so that the residual porosity of the samples was in the range of 5-6\%. 
The results of the study of the physico-mechanical properties of the asphalt binder are presented in table 5 .

Table 5. Physical and mechanical properties of asphalt binder.

\begin{tabular}{|l|c|c|}
\hline \multirow{2}{*}{ Indicators } & \multicolumn{2}{|c|}{ Mineral powder } \\
\cline { 2 - 3 } & slag & limestone \\
\hline Water saturation, \% & 1.95 & 3.02 \\
\hline Average density, kg / m3 & 2420 & 2330 \\
\hline Swelling, \% & 2.21 & 3.11 \\
\hline Tensile strength in compression, MPa, at & & \\
test temperature: & 3.10 & 1.95 \\
$50{ }^{0} \mathrm{C}$ & 6.60 & 5.25 \\
$20{ }^{0} \mathrm{C}$ & 5.20 & 3.40 \\
in a saturated state & 0.75 & 0.71 \\
\hline Water resistance & & \\
\hline
\end{tabular}

As we can see, the physical and mechanical characteristics of the asphalt binder made of slag raw materials have higher values than when using limestone as a mineral powder. Also, for samples made on slag, water saturation and swelling are significantly lower than on limestone.

An explanation of the results was performed from the standpoint of evaluating the adhesive processes occurring in the "bitumen - mineral powder" system in terms of water resistance.

Research results (table 6) show that the surface area coated with bitumen on a substrate of slag raw materials is larger than on limestone. The revealed dependence is also observed in determining the adhesion after exposure to boiling water. The stability of adhesive bonds is characterized by a coefficient of adhesive stability, which shows how much the area of the mineral material covered with bitumen changed immediately after combining with bitumen and after aging in an aggressive environment. Similar results were obtained in the study of the adhesion of bitumen with mineral materials by the gravimetric method (table. 6).

Table 6. Adhesion of bitumen with mineral materials.

\begin{tabular}{|l|c|c|c|c|}
\hline \multirow{2}{*}{ Mineral materials } & \multicolumn{3}{|c|}{ Dye Adsorption Method } & \multirow{2}{*}{$\begin{array}{c}\text { Weight } \\
\text { method,\% }\end{array}$} \\
\cline { 2 - 5 } & $\begin{array}{c}\text { before } \\
\text { boiling, } \%\end{array}$ & after boiling, \% & $\begin{array}{c}\text { adhesion } \\
\text { coefficient }\end{array}$ & 78 \\
\hline Limestone & 84 & 74 & 0.88 & 86 \\
\hline Slag & 84 & 75 & 0.89 & 78 \\
\hline
\end{tabular}

The obtained results confirm a higher intensity of the interaction of bitumen and slag compared with limestone. The data confirm the results of the table 5 and suggest that the surface of the slag is composed of a more diverse mineralogical composition characterized by a large number of active surface site compared to limestone, $\mathrm{CaO}$ was also recorded in its composition,which forms strong bonds upon contact with water due to the general hardening of the composite due to the growth of cristahydrates [15]. Also, the shape of the slag grains is better developed (Fig. 2). Obviously, the combination of these factors provides strong adhesive contacts between the binder and the surface of the slag mineral materials with the formation of new chemisorption compounds on the interface which are difficult to break even with prolonged exposure to water. 
Also, the introduction of a mineral powder into bitumen to a certain limit leads to an increase in the viscosity and cohesion of the binary system, which is reflected in the properties of organic-mineral systems which is consistent with the data in Table 4 demonstrating the increase in strength characteristics of asphalt binder samples made on slag powder compared with limestone.

Considering that the main role of a mineral powder in an asphalt concrete mixture is to transfer bitumen to a film state with the formation of oriented bonds that significantly change the nature of the properties of the binder compared to the bulk state, it becomes possible to predict the high quality of asphalt concrete where slag raw materials are present as a mineral powder.

\subsection{Assessment of the contribution of slag components on the properties of type $B$ asphalt concrete}

To research the effect of the studied aggregates and filler on the properties of the road organic-mineral composite asphalt concrete samples of type B, widely used in road paving were prepared. The study of the physics-mechanical characteristics of the road composite was carried out on samples of asphalt mixes prepared and tested in accordance with GOST 12801-98 of continuous particle size distribution and selected according to GOST 91282009 , according to the curves of dense mixtures.

The amount of mineral powder in the mixture was selected based on the principles of imparting normative density and strength to road asphalt concrete.

To study the possibility of using steel-smelting slag in the composition of asphalt concrete 4 variants of the mixture formulation were selected. The compositions used for further studies are presented in table 7 .

The aim of this stage of the experiment was to vary the amount of slag materials involved in the asphalt mix recipe, starting from replacing slag raw materials with only mineral powder in the composition of the composite (composition 2) and ending with the formation of a mineral composition consisting entirely of slag components (composition 4). As the basic composition with respect to which the comparison was carried out composition 1 prepared using crushed stone and sand as granite material of various fractions was used as dispersed limestone.

Table 7. Compositions of asphalt mixtures accepted for research.

\begin{tabular}{|c|l|l|l|l|}
\hline $\begin{array}{c}\text { Composition } \\
\text { number }\end{array}$ & Crushed stone & Sand & $\begin{array}{l}\text { Mineral } \\
\text { powder }\end{array}$ & Bitumen \\
\hline 1 & $\begin{array}{c}\text { granite - } \\
41.5 \%\end{array}$ & $\begin{array}{l}\text { granite screenings - } \\
51.5 \%\end{array}$ & $\begin{array}{l}\text { limestone - } \\
7.0 \%\end{array}$ & $\begin{array}{l}\text { BND 60/90 - } \\
5.5 \%\end{array}$ \\
\hline 2 & granite - & granite screenings - & slag - 7.0\% & $\begin{array}{l}\text { BND 60/90 - } \\
5.5 \%\end{array}$ \\
\hline 3 & $41.5 \%$ & $51.5 \%$ & slag - 11.5\% & $\begin{array}{l}\text { BND 60/90 - } \\
5.6 \%\end{array}$ \\
\hline 4 & granite - & slag - 47.0\% & slag - 10.14\% & $\begin{array}{l}\text { BND 60/90 - } \\
5.8 \%\end{array}$ \\
\hline
\end{tabular}

The test results of the physical-mechanical characteristics of type B asphalt concrete are presented in Table 8.

An analysis of the results indicates that the physical-mechanical characteristics of the asphalt concrete samples of the studied compositions 1 and 2 are close and meet the requirements of GOST; moreover, the asphalt concrete indicators made of slag aggregate are not inferior to those for a composite on traditional mineral powder and the water 
resistance of the experimental asphalt concrete samples is slightly higher ( 0.95$)$ than the control (0.89). It was established by the example of a binary system evidence of a good adhesion of the mineral powder from slag to bitumen.

Thus, the finely ground slag fraction can be used as a mineral powder in the composition of asphalt mixtures.

The test results of compositions 3 and 4 indicate high physical and mechanical characteristics of samples of asphalt concrete of both compositions. Composition 4 where the entire mineral part consists of slag materials shows an increase in strength at $500{ }^{\circ} \mathrm{C}$ compared with other experimental and control composition of asphalt concrete, as well as water resistance. However, this composition is characterized by a high average density which makes it non-technological and unprofitable from the point of view of transporting asphalt concrete mixture to a building object and laying it in a coating.

Table 8 .Test results of type B asphalt concrete.

\begin{tabular}{|c|c|c|c|c|c|}
\hline \multirow[t]{2}{*}{ Indicator } & \multirow[t]{2}{*}{$\begin{array}{c}\text { Нормы ГОСТ } \\
9128-2009\end{array}$} & \multicolumn{4}{|c|}{$\begin{array}{l}\text { Number of composition of the asphalt } \\
\text { mix }\end{array}$} \\
\hline & & 1 & 2 & 3 & 4 \\
\hline Average density, $\mathrm{g} / \mathrm{cm}^{3}$ & - & 2.41 & 2.51 & 2.66 & 3.17 \\
\hline Water saturation, $\%$ & $1.5-4.0$ & 1.8 & 2.0 & 3.7 & 4.0 \\
\hline $\begin{array}{l}\text { Limit of compressive strength } \\
\text { at temperature, MPa: } 20^{\circ} \mathrm{C}\end{array}$ & $\begin{array}{l}\text { not less than } \\
2.2\end{array}$ & 6.0 & 6.2 & 6.8 & 7.8 \\
\hline $50^{\circ} \mathrm{C}$ & $\begin{array}{c}\text { not less than } \\
1.2\end{array}$ & 2.0 & 2.2 & 2.7 & 3.6 \\
\hline $0^{0} \mathrm{C}$ & $\begin{array}{l}\text { not more than } \\
12\end{array}$ & 11.0 & 11.0 & 11.8 & 12.2 \\
\hline Water resistance & $\begin{array}{c}\text { not less than } \\
0.85\end{array}$ & 0.89 & 0.95 & 0.94 & 0.95 \\
\hline Porosity, $\%$ & $\begin{array}{c}\text { not more than } \\
19\end{array}$ & 14.8 & 14.3 & 16.0 & 18.0 \\
\hline
\end{tabular}

From the test results we can conclude that the characteristics of the mineral powder made of slag raw materials allow the full replacement of limestone mineral powder in the technology of production of asphalt concrete. The resulting mixture will fully satisfy the requirements of GOST. Sand from the screening crushing slag allows us to get a mixture that meets the requirements of regulatory documentation, however, we must provide additional measures to improve it. The use of slag crushed stone, in our opinion, as part of asphalt concrete is not advisable. However, for a final assessment of the possibility of using slag components, it is necessary to conduct a series of studies aimed at identifying the patterns of behavior of such asphalt concrete in time and under the conditions of exposure to aggressive environmental factors and traffic loads.

\subsection{Modeling the influence of transport load on the studied compounds}

Modern directions in the design of asphalt concrete are based on increasing the accuracy of predicting the durability of materials in road surfaces, depending on specific operating conditions. The more accurately the working conditions of the asphalt concrete in the pavement are taken into account the more reliable the asphalt concrete can be designed.

The existing traffic intensity and an increase in axial loads significantly affect the road surface and the structure as a whole which leads to various defects including those associated with a decrease in the fatigue life of asphalt concrete in the coating. 
Due to the fact that at the stage of studying the physicomechanical parameters of type B asphalt concrete without additional reservations, only composition 2 was found, in the study on fatigue life, samples from series 1 (control on limestone) and 2 on slag were examined. The experiment was carried out in 2 stages: at the first stage, the parameters of the stiffness modulus of a part of asphalt concrete samples were determined after 2 days, and at the second stage, samples from the same series were tested, which were in air storage for 45 days.

During the test, 2 parameters were evaluated: the initial stiffness modulus and the number of loading cycles until the initial stiffness modulus fell by $50 \%$ cycles. The results are presented in table 9 .

Table 9. The results of laboratory tests of fatigue life of type B asphalt concrete at different time intervals.

\begin{tabular}{|l|c|c|c|}
\hline $\begin{array}{l}\text { Asphalt concrete } \\
\text { type B series } \\
\text { No. }\end{array}$ & $\begin{array}{c}\text { Initial stiffness } \\
\text { modulus, MPa }\end{array}$ & $\begin{array}{c}\text { The number of } \\
\text { loading cycles until } \\
\text { the initial stiffness } \\
\text { modulus drops by } \\
50 \% \text { cycles, thousand }\end{array}$ & $\begin{array}{c}\text { Rigidity modulus } \\
\text { at the end of the } \\
\text { test, MPa }\end{array}$ \\
\hline \multicolumn{4}{|c|}{ Sample testing time on 2 days after manufacture } \\
\hline series №1 & 2931 & 1200 & 1467 \\
\hline series № 2 & 2377 & 1019 & 1156 \\
\hline \multicolumn{4}{|c|}{ Sample testing time for 45 days after manufacture } \\
\hline series №1 & 3280 & 929 & 1657 \\
\hline series № 2 & 3114 & 1003 & 1554 \\
\hline
\end{tabular}

The results show that more rigid mixtures in the initial period was prepared using limestone. Fatigue life of asphalt concrete - the number of cycles sustained by asphalt concrete samples to failure at specified loading parameters. Pavement vibrations are a reaction of a pavement to a dynamic effect, which manifests itself in the form of oscillatory movement of pavement points over a certain time interval.

However, after 45 days in the room, samples of series 1 and 2 showed an inverse relationship. When using limestone mineral powder, the set of hardness occurred in the expected range and amounted to no more than $12 \%$ of the initial value, while samples with slag 2 showed a rapid increase in the test parameter and embrittlement. The increase in stiffness modulus was $31 \%$.

Thus, the results show that under such loading conditions, according to the obtained fatigue life data of asphalt concrete, which uses slag, additional studies are needed that go beyond the standard tests of asphalt concrete samples or it is necessary to change the test conditions which will determine the permissible use cases mineral powder from steel slag and type of asphalt concrete.

\section{Conclusion}

Such studies are relevant, allowing a comprehensive approach to solving a number of problems: man-made mineral materials are a source of inexpensive and often prepared raw materials which leads to energy savings, in addition, it opens the possibility of unloading numerous dumps and landfills liberating fertile lands. Due to the fact that preserving the quality of the environment and public health is among the most pressing problems of our time gradually the problems of improving the environmental situation come to the fore, pushing aside even the economic or social aspects of human life, as ultimately all the 
results are "inattentive" relations to the natural environment are reflected in a person - his health, ability to work, quality and life expectancy.

As a result of the study, it was found that a promising area for the use of slag raw materials in the technology for making asphalt mixes is: as a mineral powder - without additional processing steps; crushing screening - with the development of additional technological operations. The use of raw materials as gravel is impractical because of the high average density of the resulting asphalt mixture.

Based on the test results, the characteristics of the fatigue properties of asphalt concrete from fine-grained dense mixtures of type B, made on mineral powders from slag and limestone, were obtained. It was established that at the initial moment, a large number of cycles to failure are characterized by compositions 2 based in slag powder, however, samples from this series tested showed a significant increase in stiffness and were destroyed earlier than similar samples on limestone after 45 days. Obviously, this phenomenon is associated with an increase in brittle material properties due to the formation of crystallization-condensation bonds in the structure of asphalt concrete containing slag. Those signs of "monolithing" begin to appear.

Thus, we can conclude that when working with unconventional raw materials, a comprehensive assessment of their characteristics is necessary with the forecasting of possible risks from their use, as well as the possibility of their compensation through rational and correctly selected technology of use.

\section{References}

1. Y. Huang, X. Guoping, C. Huigao. W. Junshi, W. Yinfeng, Hui Chen Procedia Environmental Sciences 16, 791-801, (2012). DOI: 10.1016/j.proenv.2012.10.108

2. P. Ahmedzade, B. Sengoz, Journal of Hazardous Materials 165(1-3), 300-305, (2009). DOI: $10.1016 /$ j. jhazmat.2008.09.105

3. A.Behnood, M.Ameri, Scientia Iranica 19(5), 1214-1219, (2012). DOI:10.1016/j.scient.2012.07.007

4. Jian-Shiuh Chen, Shih-Hsiu Wei Construction and Building Materials 128, 148-153, (2016). DOI: 10.1016 / j. conbuildmat.2016.10.02

5. K. L.Magadi, N. Anirudh, K. M. Mallesh Transportation Research Procedia 17, 174-183, (2016), DOI: 10.1016 / j. trpro.2016.11.073

6. K.G. Pugin, V.S. Yushkov Ecology and Industry of Russia, 21 (5), pp. 4-7 (2017) DOI: 10.18412/1816-0395-2017-5-4-7

7. İslam Gökalp, Volkan Emre, Uza Mehmet Saltan, Erol Tutumluer Transportation Geotechnics, 14, pp. 61-69 (2018) DOI: 10.1016/j.trgeo.2017.10.003

8. Ashish Kumer, M.N. Saha, N. Khan, Prabir Kumar Sarker Resources, Conservation and Recycling 134, 10-24, (218). DOI: 10.1016/j.resconrec.2018.02.034

9. E. A. Oluwasola, M. R. Hainin, M. M. A. Aziz, Transportation Geotechnics 2, 47-55, (2015). DOI: 10.1016/j.trgeo.2014.09.004

10. S. Sorlini, A. Sanzeni, L. Rondi, Journal of Hazardous Materials 209-210, 84-91, (2012). DOI: 10.1016/j.jhazmat.2011.12.066

11. M. Paliukaite, V. Vorobjovas, M. Bulevičius, V. Andrejevas, Transportation Research Procedia 14, 724-731, (2016). DOI: 10.1016/j.trpro.2016.05.339

12. T. Schlegel, D. Puiatti, H.-J. Ritter, D. Lesueur, C. Denayer, A. Shtiza, Transportation Research Part D, Transport and Environment 48, 141-160, (2016). DOI:10.1016/j.trd.2016.08.005 
13. D.I. Gofman, M.V. Katasonov, A.V. Kochetkov, Yu.A. Gaydaychuk, D.I. Kirichuk Transport facilities 5(4), 19, (2018). DOI: 10.15862/22SATS418

14. H. Wang, I. L. Al-Qadi, A. F. Faheem, H. U. Bahia Shih-Hsien Yang, G. H. Reinke, Transportation Research Record Journal of the Transportation Research Board 2208(1), 33-39, (2011). DOI: 10.3141/2208-05

15. J. S. Chen, S. H. Wei, Construction and Building Materials 128, 148-153, (2016). DOI: 10.1016/j.conbuildmat.2016.10.027 